\title{
Sarcoidosis and antiphospholipid syndrome: A rare association
}

\author{
Rosa Carvalho*1, Vânia Gomes ${ }^{1}$, Raquel Pereira ${ }^{1}$, Adelaide Moutinho ${ }^{2}$, Anna Knoch ${ }^{1}$, Céu Rodrigues ${ }^{1}$, Carlos Capela ${ }^{1}$ \\ ${ }^{1}$ Internal Medicine Service, Hospital de Braga, Braga, Portugal \\ ${ }^{2}$ Internal Medicine Service, Centro Hospitalar de Tràs-os-Montes e Alto Douro, Hospital de Chaves, Chaves, Portugal
}

Received: February 10, 2017

DOI: $10.5430 /$ crim.v4n $3 p 28$
Accepted: May 22, 2017

Online Published: June 25, 2017

\begin{abstract}
Sarcoidosis is a systemic inflammatory disorder of unknown cause that is characterized by the granulomatous inflammation of various organs. Antiphospholipid syndrome (APS) is an autoimmune condition defined by persistently positive antiphospholipid antibodies as well as recurrent arterial or venous thromboses and pregnancy complications. Several autoimmune diseases have been described in patients with sarcoidosis, however, a possible correlation between sarcoidosis and APS remains unknown. We present the fifth reported case in the literature.
\end{abstract}

Key Words: Sarcoidosis, Antiphospholipid syndrome, Association, Autoimmune diseases

\section{INTRODUCTION}

Sarcoidosis is a chronic multisystemic non-caseating granulomatous disease of unknown cause. ${ }^{[1]}$ Antiphospholipid syndrome (APS) is a clinical condition characterized by recurrent thrombotic events and/or pregnancy morbidity associated with the persistence of antiphospholipid antibodies. ${ }^{[2]}$ The relationship of sarcoidosis and APS is not clearly understood and the possibility of these two entities share pathophysiological mechanisms has been explored. Both APS and sarcoidosis have been known to occur with autoimmune conditions ${ }^{[3,4]}$ and even though studies have found an association between antiphospholipid antibodies and sarcoidosis, ${ }^{[5-7]}$ cases with both sarcoidosis and APS are extremely rare. ${ }^{[8-12]}$

\section{Case presentation}

A 51-year-old white male patient presented to the Internal Medicine consult with a 6-day painless, unilateral swelling of the right lower limb, with no associated signs of inflam- mation, skin changes or trauma history, and the doppler ultrasound revealed Deep Vein Thrombosis (DVT) at popliteal and femoral veins. The patient's past medical history included hypertension, dyslipidemia, obesity as well as sarcoidosis. The sarcoidosis was diagnosed in 1997 with multiorganic involvement (lung, liver and skin) and hypercalcemia, by performing a liver biopsy that revealed the presence of noncaseating granulomas. The patient was treated with corticosteroids and immunosuppressants for years, but as the patient was asymptomatic, the therapy was discontinued 5 years before the presentation on our consult. After the diagnosis of DVT, the patient was placed on low molecular weight heparin (80 mg twice daily) and investigated. An initial prothrombotic study was made, with positive results for lupus anticoagulant activity, anticardiolipin immunoglobulin $\mathrm{M}(\operatorname{IgM})$ antibodies of $54 \mathrm{U} / \mathrm{ml}$ (normal range between 0-15 U/ml) and anti-beta2-glicoprotein IgM antibodies also positive of $56.7 \mathrm{U} / \mathrm{ml}$ (normal range $<20 \mathrm{U} / \mathrm{ml}$ ). Antinuclear and Antineutrophil antibodies were negative. Determination

\footnotetext{
*Correspondence: Rosa Carvalho; Email: rosa.macedo.carvalho@gmail.com; Address: Internal Medicine Service, Hospital de Braga, Rua das Sete Fontes, 4700, Braga, Portugal.
} 
of C and S Protein, homocystein, antithrombin III, as well as search for factor V Leiden and Prothrombin gene were negative. The prothrombotic study was repeated after 12 weeks, maintaining persistently positive antiphospholipid antibodies, fulfilling the Sapporo criteria for APS. The patient was treated with low molecular weight heparin acutely followed by lifelong warfarin. There weren't reported further thrombotic events while on anticoagulation and the patient remains on follow-up consult, asymptomatic.

\section{DisCuSSION}

Only four definite cases of APS and sarcoidosis have been reported in the literature. ${ }^{[8]}$ Both APS and sarcoidosis share immune dysregulation and autoimmunity, ${ }^{[3,4]}$ which might explain their co-occurrence. ${ }^{[8]}$ It is thought that an exaggerated cellular immune response in target tissues in patients with sarcoidosis is caused by exposure to an unknown antigen and the antiphospholipid antibody syndrome seems to be mediated by an autoimmune antibody response which leads us to think that a common antigenic stimulus may be in the genesis of both processes. ${ }^{[13]}$ Ina et al. investigated the level of antiphospholipid antibodies in 55 sarcoidosis patients and detected these antibodies in $38 \%$ of the sample, describing a correlation between the presence of antiphospholipid antibodies and the existence of sarcoidotic extrathoracic lesions. ${ }^{[7]}$ Diagnosis of APS is made according to the revised Sapporo criteria, ${ }^{[14]}$ which requires at least one clinical (vascular thrombosis or pregnancy morbidity) and one laboratory criteria (presence of lupus anticoagulant and immunoglobulin $\mathrm{G}$ [IgG], and/or IgM anticardiolipin antibody, and/or IgG and/or IgM anti-beta 2 glycoprotein antibody). All antibodies must be demonstrated on two or more occasions separated by least 12 weeks, as we described in this clinical case. ${ }^{[8]}$ Our patient has a definite diagnosis of sarcoidosis and fulfills the modified Sapporo criteria for definite APS. It was a male patient, which argues against all the previous four cases described where all the patients were females. ${ }^{[8]}$ Interestingly, DVT is the most common thrombotic complication of APS in a large European cohort ${ }^{[15]}$ and in this case, was the leading thrombotic event. Several reports describe thrombotic events in sarcoidoisis patients, unfortunely the level of antiphospholipid antibody was not measured making it hard to prove the existence of APS. ${ }^{[3]}$ On the other hand, diagnosis of APS in a patient that doesn't have active granulomatous inflammation as in the presented case can argue against a pathophysiological link between this two entities. We agree that further reporting of cases and more pathophysiological studies will help to better define this association, determine if APS is a prognostic marker of sarcoidosis, and provide details on whether treating the underlying sarcoidosis may reduce the thrombotic risk in this subset of APS. ${ }^{[8]}$

\section{Conclusion}

Sarcoidosis and APS are chronic conditions of immune dysregulation whose etiologies remain mysterious. ${ }^{[16]}$ This case report shows a very rare association that can be either an occasional finding, or, as they can share some pathophysiological mechanisms, have a possible correlation not yet understood. However, APS should be considered as a differential diagnosis in the presence of a thrombotic event in patients with sarcoidosis regardless the activity of the disease. Progressive study of the molecular pathways involved in these diseases and research for antiphospholipid antibodies in patients with sarcoidosis, may reveal more information about shared immunopathologic mechanisms underlying these conditions.

\section{CONFLICTS OF INTEREST Disclosure}

The authors have declared no conflicts of interest.

\section{REFERENCES}

[1] Carragoso A, Silva JR, Capelo J, et al. A patient with sarcoidosis and antiphospholipid syndrome. European Journal of Internal Medicine. 2008; 19(8): e80-1. PMid:19046709 https://doi.org/10.101 $6 / j \cdot e j i m .2008 .01 .020$

[2] Bohgaki M, Matsumoto M, Atsumi T, et al. Plasma gelsolin facilitates interaction between $\beta 2$ glycoprotein I and $\alpha 5 \beta 1$ integrin. 2011; 15(1): $141-51$.

[3] Takahashi F, Toba M, Takahashi K, et al. Pulmonary sarcoidosis and antiphospholipid syndrome. Respirology. 2006; 11: 506-8. PMid:16771926 https ://doi .org/10.1111/j.1440-1843. 20 $06.00880 . x$

[4] Sharma OP. Sarcoidosis and other autoimmune disorders. Curr Opin Pulm Med. 2002; 8: 452-6. PMid:12172452 https ://doi .org/10 $.1097 / 00063198-200209000-00019$
[5] Biggioggero M, Meroni PL. The geoepidemiology of the antiphospholipid antibody syndrome. Autoimmun Rev. 2010; 9: A299304. PMid:19932199 https://doi.org/10.1016/j.autrev.2 009.11 .013

[6] Morgenthau AS, Iannuzzi MC. Recent advances in sarcoidosis. Chest. 2011; 139: 174-82. PMid:21208877 https://doi.org/10.1378/ chest.10-0188

[7] Ina Y, Takada K, Yamamoto M, et al. Antiphospholipid antibodies. A prognostic factor in sarcoidosis? Chest. 1994; 105: 1179-83. https://doi.org/10.1378/chest.105.4.1179

[8] Pathak R, Khanal R, Aryal MR, et al. Sarcoidosis and Antiphospholipid Syndrome: A Systematic Review of Cases. North American Journal of Medical Sciences. 2015; 7(9): 379-83. PMid:26605200 https://doi.org/10.4103/1947-2714.166213

[9] Esen BA, Kiyan E, Küçükkaya RD, et al. Antiphospholipid syn- 
drome presenting as massive pulmonary embolism in a patient with sarcoidosis. Eur J Gen Med. 2006; 2: 173-6.

[10] Comarmond C, Cacoub P. Antiphospholipid syndrome: From pathogenesis to novel immunomodulatory therapies. Autoimmun Rev. 2013; 12: 752-7. PMid:23282546 https://doi.org/10.1016/ j.autrev.2012.12.006

[11] García-Gallo CL, Ussetti P, Díaz B, et al. Sarcoidosis pulmonar y síndrome antifosfolipídico. Arch Bronchoneumol. 2003; 39: 187-9.

[12] Toba F, Takahashi M, Tominaga K, et al. Pulmonary sarcoidosis and antiphospholipid syndrome. Respirology. 2006; 11: 506-8. PMid:16771926 https://doi .org/10.1111/j.1440-1843.20 $06.00880 . x$

[13] Sattia SD, Barholomewb J, Gordonc SM, et al. Antiphospholipid antibody syndrome in a patient with neurosarcoidosis. Vascular Medicine.
1999; 4: 37-9. PMid:10355869 https://doi.org/10.1177/13 $58836 \times 9900400107$

[14] Wilson WA, Gharavi AE, Koike T, et al. International consensus statement on preliminary classifi cation criteria for defi nite antiphospholipid syndrome: Report of an international workshop. Arthritis Rheum. 1999; 42: 1309-11. https ://doi .org/10.1002/1529-0 131(199907) 42:7<1309: : AID-ANR1>3.0.CO;2-F

[15] Cervera R, Piette JC, Font J, et al. Antiphospholipid syndrome: Clinical and immunologic manifestations and patterns of disease expression in a cohort of 1,000 patients. Arthritis Rheum. 2002; 46: 1019-27. PMid:11953980 https://doi.org/10.1002/art.10187

[16] Costenbader KH, Coblyn JS. Co-existing sarcoidosis, systemic lupus erythematosus and the antiphospholipid antibody syndrome: Case Reports and Discussion from the Brigham and Women's Hospital Lupus Center. Lupus. 2009; 18(3): 202-5. PMid:19213857 https://doi.org/10.1177/0961203308100483 